\title{
Archaeological Investigations at Eisenhower Park, Northern Bexar County, Texas
}

\author{
A. Joachim McGraw
}

Follow this and additional works at: https://scholarworks.sfasu.edu/ita

Part of the American Material Culture Commons, Archaeological Anthropology Commons, Environmental Studies Commons, Other American Studies Commons, Other Arts and Humanities Commons, Other History of Art, Architecture, and Archaeology Commons, and the United States History Commons

Tell us how this article helped you.

This Article is brought to you for free and open access by the Center for Regional Heritage Research at SFA ScholarWorks. It has been accepted for inclusion in Index of Texas Archaeology: Open Access Gray Literature from the Lone Star State by an authorized editor of SFA ScholarWorks. For more information, please contact cdsscholarworks@sfasu.edu. 
Archaeological Investigations at Eisenhower Park, Northern Bexar County, Texas

Creative Commons License

(C) $(1) \Theta$

This work is licensed under a Creative Commons Attribution-NonCommercial 4.0 International License 


\title{
ARCHAEOLOGICAL INVESTIGATIONS AT EISENHOWER PARK, NORTHERN BEXAR COUNTY, TEXAS
}

\author{
A. Joachim McGraw
}

Center for Archaeological Research

The University of Texas at San Antonio

Archaeological Survey Report, No.167

1986 

Genter for Aroheslogisal Mosearch The Univarsivy of Taxes at San Antanis San Antenio, Texas 78285 



\section{ARCHAEOLOGICAL INVESTIGATIONS \\ AT EISENHOWER PARK, \\ NORTHERN BEXAR COUNTY, TEXAS}

A. Joach im McGraw

Submitted to the San Antonio

Parks and Recreation Department

Texas Antiquities Committee Permit No. 522

Center for Archaeological Research The University of Texas at San Antonio ${ }^{\circ}$ Archaeological Survey Report, No. 167 
The following information is provided in accordance with the General Rules of Practice and Procedure, Chapter 41.11 (Investigative Reports), Texas Antiquities Committee:

1. Type of investigation: survey and limited subsurface testing;

2. Project name: Eisenhower Park;

3. County: Bexar;

4. Principal investigator: Thomas R. Hester; co-principal investigator: Jack D. Eaton;

5. Name and location of sponsoring agency: San Antonio Parks and Recreation Department, San Antonio, Texas;

6. Texas Antiquities Committee Permit No. 522;

7. Published by the Center for Archaeological Research, The University of Texas at San Antonio 78285-0658, 1986.

A 1 ist of publications offered by the Center for Archaeological Research can be obtained by sending $\$ 1.00$ to the Center for Archaeological Research, The University of Texas at San Antonio, San Antonio, Texas 78285-0658. 


\section{TABLE OF CONTENTS}

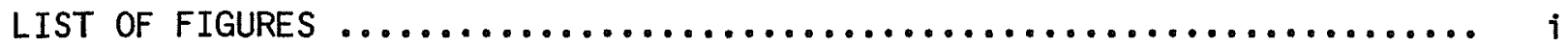

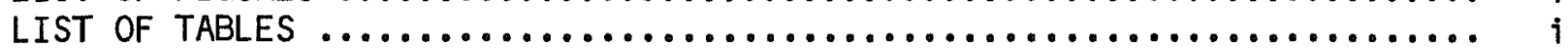

ABSTRACT ........................................

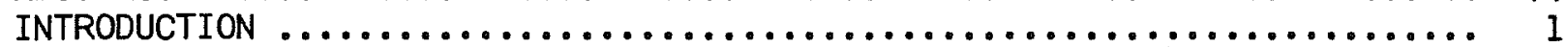

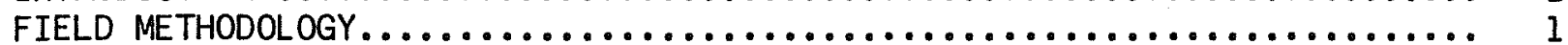

DESCRIPTION OF THE STUDY AREA $\ldots \ldots \ldots \ldots \ldots \ldots \ldots \ldots \ldots \ldots \ldots \ldots \ldots \ldots \ldots \ldots \ldots \ldots . \ldots \ldots$

ARCHAEOLOGICAL BACKGROUND $\ldots \ldots \ldots \ldots \ldots \ldots \ldots \ldots \ldots \ldots \ldots \ldots \ldots \ldots \ldots \ldots \ldots \ldots$

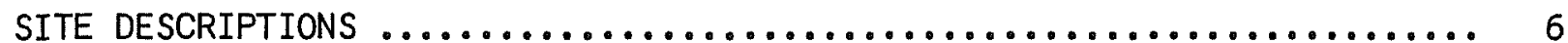

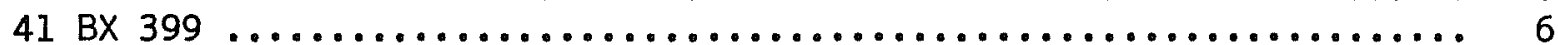

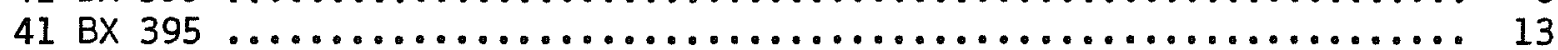

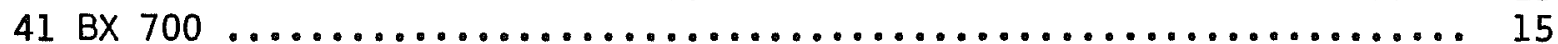

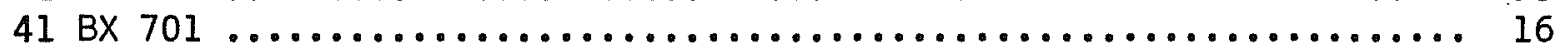

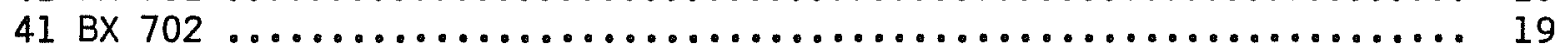

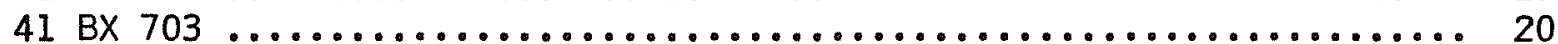

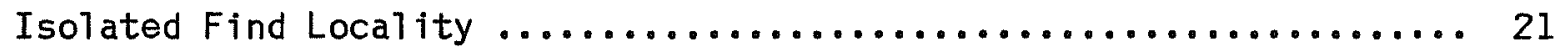

SUMMARY ............................................. 21

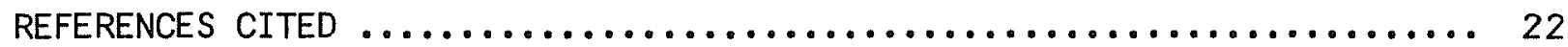

\section{LIST OF FIGURES}

1. Generat Location of Study Area .......................... 3

2. The Eisenhower Park Project Area .......................... 9

3. Collected Artifacts .................................. 11

\section{LIST OF TABLES}

1. Results of Subsurface Testing, 41 BX $399 \ldots \ldots \ldots \ldots \ldots \ldots \ldots \ldots \ldots$

2. Results of Subsurface Testing, 41 BX $395 \ldots \ldots \ldots \ldots \ldots \ldots \ldots \ldots \ldots \ldots \ldots \ldots . . \ldots 14$

3. Results of Subsurface Testing, 41 BX $701 \ldots \ldots \ldots \ldots \ldots \ldots \ldots \ldots \ldots \ldots$ 


\section{ABSTRACT}

During December 1985, a cultural resources assessment was made within the 350-acre property of Eisenhower Park in northern Bexar County, Texas. Systematic survey of the property and 1 imited subsurface testing at four new $7 y$ recorded and two previously recorded prehistoric sites were done. Al1 sites are characterized by a deflated scatter of 1 ithic debris. None of the sites examined are deemed potentially eligible for nomination to the National Register of Historic Places or to be designated as a State Archeological Landmark. 


\section{INTRODUCTION}

During December 1985, personnel from the Center for Archaeological Research (CAR), The University of Texas at San Antonio (UTSA), conducted an intensive archaeological survey and limited testing within the 350-acre property of Eisenhower Park in northern Bexar County, Texas. The work was conducted under contract between the City of San Antonio, Parks and Recreation Department, and the CAR-UTSA (City Ordinance 61584, October 10, 1985, and 1etter of transmittal dated October 14, 1985). The purpose of the work was to assess the significance of identified archaeological sites and their potential for nomination to the National Register of Historic Places and/or to be designated as a State Archeological Landmark. The investigations were carried out by $A$. Joachim McGraw and Bruce El 1 is of the Center staff during the period from December 4-17. The project was conducted under Texas Antiquities Committee Permit No. 522. A1 1 work was done under the genera 1 direction of Thomas R. Hester, Center Director, and Jack D. Eaton, Associate Director. The maps and artwork for the cover for this report were drawn by Bruce EIIis, and the artifact 111 ustrations were drawn by Cathy Dodt.

\section{FIELD METHODOLOGY}

Field methodology consisted of two distinct but related elements: (1) as close as possible to a $100 \%$ intensive surface survey of the park area, and (2) 1 imited subsurface examination in the form of multiple $50-\mathrm{cm}^{2}$ shove 1 tests across individually defined site areas. While pedestrian surveys found some areas, due to the density of vegetation and nature of the terrain, difficult to traverse, a11 park property was inspected and assessed.

Fol lowing the relocation of two previously recorded sites (4I BX 395 and $41 \mathrm{BX} 399$ ) and the identification of four additional sites (4I BX 700 , $41 \mathrm{BX} 701,41 \mathrm{BX} 702,41 \mathrm{BX} 703$ ), a change was initiated in the investigative strategy. After intensive survey, assessment of the sites investigated, and redefinition of the material and physical characteristics of the prehistoric activity areas, subsurface examination (multiple $50-\mathrm{cm}^{2}$ shovel tests) was considered to be more productive, practical, and cost-effective than the previously recommended (Gerstle, Kel1y, and Assad 1978:343-344) mapping of the site area(s) (see Site Descriptions, 41 BX 395 and 41 BX 399, for a detailed discussion for this change of methodology). Subsurface testing in a 11 identified site areas was conducted not only to identify the vertica 1 depth (or 1 ack of) of material deposits but also to verify the extent of site deflation and depositional integrity; if present. In all recorded site areas, intensive survey suggested extensive if not severe natural deflation of activity locations. Given the density of juniper and difficulty of access because of slope and terrain, the mapping of scattered, deflated 1 ithic debris was considered to be unproductive and ineffectual.

The field survey was accomplished by two persons spaced at 20 to $35-m$ intervals, depending upon terrain and ground cover. Subsurface testing was based upon a judgmental sampling procedure in which the horizontal site 1 imits were defined and material concentrations noted, if any. Systematic interval sampling across the individual site areas was utilized when no identifiable materials were readily observed; the frequency of sampling was 
based on a determination of site subsurface potential. Al1 recorded sites were plotted on USGS 7.5' topographic maps and smal1 scale 1:200 project maps furnished by the San Antonio Parks and Recreation Department.

A11 new 1 y assessed locations were recorded on state survey forms, and col 1ections were made of chronologically diagnostic or otherwise significant artifacts. A11 site locations were revisited to review the accuracy of initial estimates of site description, location, and dimension. Field notes, photographs, collected artifacts, and other site information are on file at the CAR-UTSA.

\section{DESCRIPTION OF THE STUDY AREA}

The study area is situated on the southern margins of the Edwards Plateau in northern Bexar County. As such, the immediate vicinity of the park area includes the Balcones Fault Zone, a physiographic area identified as a recharge zone of the Edwards Aquifer. The Balcones Escarpment separates the Edwards Plateau from the Gulf Coastal Plain to the south and east (BIair 1950; see also Carr 1967). The study area, encompassing an upland hilltop/ridge complex, divides the watershed of two major drainages of northern Bexar County: the Salado Creek drainage to the east and the upper Leon Creek drainage to the west. The major channels of each of these hydrological systems are currently located ca. $1.5 \mathrm{~km}$ from the park. In ancient times, the former floodplain of Leon Creek may have been much closer to the western portion of the study area (see Fig. 1).

The physiography of northern Bexar County is characterized by eroded 1 imestone hills dissected by intermittent, deeply incised drainages in relatively wide floodplains. This is, according to modern geological interpretations (W. Hammond, Associate Professor of Geology, UTSA, personal communication), due to a long history of major flooding episodes that have scoured broad, $10 w-1$ ying areas adjacent to otherwise ephemera 11 y f1owing stream channel s. High energy flash floods are a wel1-known phenomenon of modern weather patterns in Bexar County, and such episodes are thought to have had their antecedents in much earlier times, since the beginning of the Holocene epoch.

The soil surrounding the study area is of the Tarrant-Brackett series (Freese and Nichols, Inc. 1977). The soil is shallow and calcareous overlying the lower Glen Rose or Edwards Limestone formations.

The flora and fauna of the area have been discussed in some detail by Freese and Nichols. Inc. (1977). Gerstle, Kel1y, and Assad (1978:28-29) also present a 1 ist of past and modern biota that may have been exploited by aboriginal groups in the area.

The study area forms the southern margins of the Balconian Biotic Province; it also contains a mixture of flora and fauna related to the Tamaulipan and Texan Biotic Provinces to the south and east (B1air 1950). Climax vegetation includes several subgroups of oak as well as mesquite, juniper, shin oak, Texas oak, persimmon, and hackberry. Tamaulipan associated flora, common along the hil1slopes, includes catclaw, twisted-leaf yucca, Spanish dagger, 


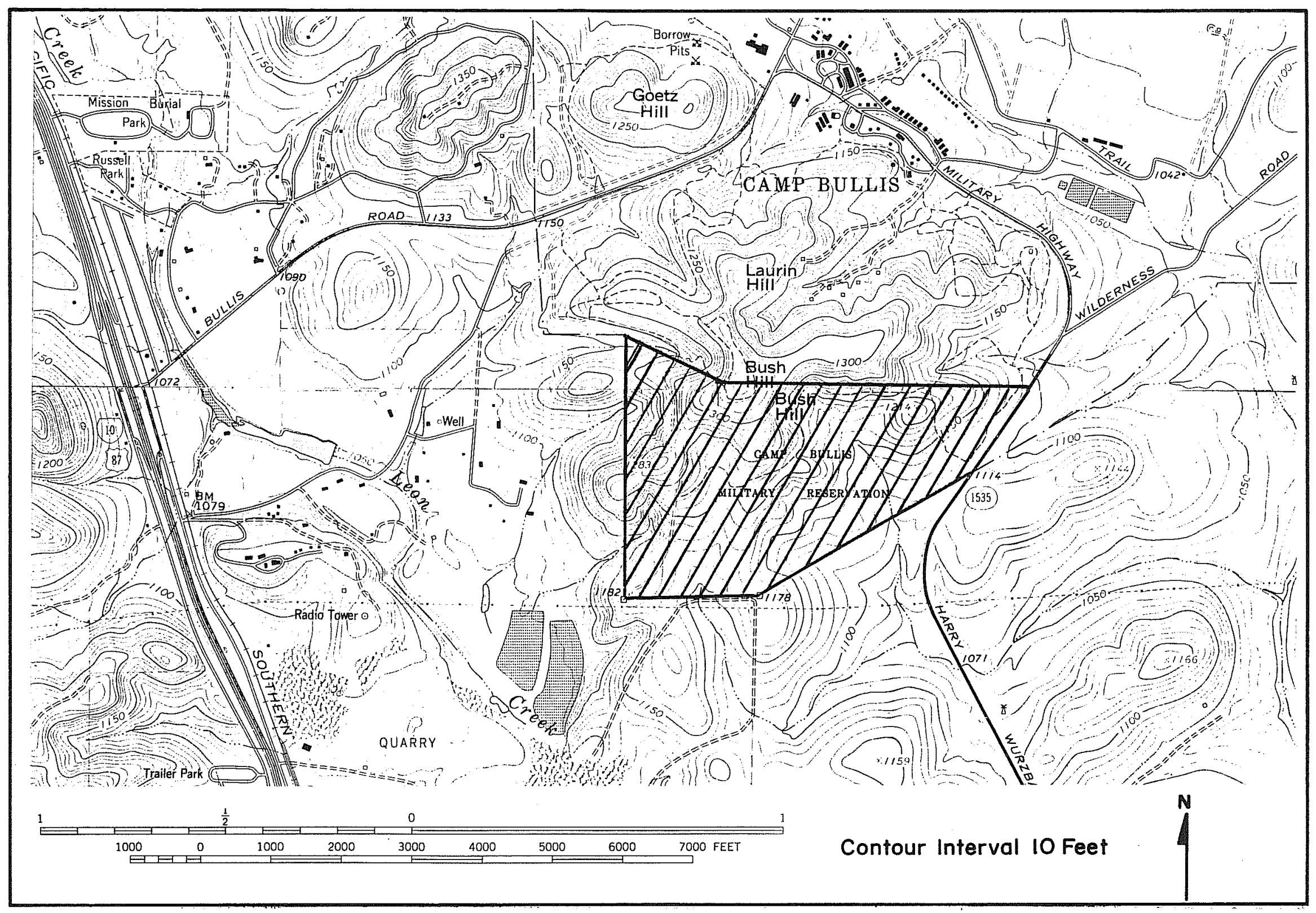

Figure 1. General Location of Study Area. Drawing adapted from USGS 7.5' maps: Camp Bu11 is Quad and Cast1e Hi 11 Quad. 
sotol, and tasajil10. Indigenous fauna includes white-tajled deer and javelina, as well as a number of smaller animals such as fox squirrel, armadil10, cottontail rabbit, jackrabbit, striped skunk, pocket gopher, and a wide variety of snakes.

The area's climate is usual 1 y described as modified subtropical and falls within a climatological transition zone of the Edwards Plateau, southcentral, and upper coast divisions. Prevailing winds are southeasterly for most of the year except in the winter months. From the years 1931 to 1960 , the average winter temperature was $53.7^{\circ} \mathrm{F}$, and the average summer temperature was $83.2^{\circ} \mathrm{F}$ (Taylor, Hailey, and Richmond 1966). Rainfal1, especially shortterm heavy downpours, are characteristic of this area, and McGraw and Hindes (n.d.) note that Bexar County has the third highest maximum 24-hour recorded rainfa 11 rate in a 17 -county area.

In summary, the environmental characteristics are reflective of the Balcones Escarpment of the Edwards Plateau. From an archaeological perspective, the upland natural setting of the study area has influenced both the extent and frequency of aboriginal exploitations.

\section{ARCHAEOLOGICAL BACKGROUND}

Within the 1 ast 10 years, a number of archaeological investigations have occurred in Bexar County, and such work has contributed significantiy to the understanding of quickly diminishing 1 ocal cultural resources. In many cases, especially northern San Antonio, the extent of identification, documentation, and assessments of a large number of archaeological sites has been overshadowed by the accelerated destruction of additional sites through relic collecting, suburban expansion, and commercial development.

Published archaeological reports concerning Bexar County sites date to the 1930s. It was, however, not until 40 years 1 ater that a review of the prehistory of the county was presented by Fawcett (1972), along with the environmental characteristics and description of archaeological sites, to that date, of the area. Following work by Fox (n.d.) and Schuetz (1966), Dibble (1979) conducted a preliminary archaeological survey along portions of Salado Creek in northern Bexar County.

Since 1974, cultural resources management studies have increased the local information base. The Fort Sam Houston/Camp Buli is project reported by Gerstle, Kelly, and Assad (1978) is directly related to this current work and is the source of the original data for the two previously recorded sites (41 BX 395 and 41 BX 399). Studies, such as those conducted by McGraw and Valdez (1978a, 1978b), McGraw, Valdez, and Cox (1977), and more recent1y, Black and McGraw (1985), have contributed substantially to the understanding of the local archaeological record. B1ack and McGraw (1985) present a detailed discussion of northern Bexar County and 1 ist a local chronological sequence for the area. To a lesser extent, Gerstle, Kel1y, and Assad (1978) al so present descriptive reviews of major archaeological sites in the northern part of the county. Most recently, McGraw and Hindes ( $n$.d.) have completed an extensive prehistoric, historic Indian, and historical overview 
of southwestern Bexar County; their detailed, general background data is app 1 icable to this study area.

A more detailed review of previous research is beyond the scope of this report, and the reader is referred to Black and McGraw (1985), Gerst1e, Kel1y, and Assad (1978), and McGraw and Hindes (n.d.) for further discussions and references of earlier work in this area.

The chronological framework for northern Bexar County can be traced to at least 9200-8150 B.C. by the occurrence of Folsom and Clovis Paleo-Indian projectile points recovered from $41 \mathrm{BX} 52$, ca. $2.5 \mathrm{~km}$ southwest of Eisenhower Park along Leon Creek. Paleo-Indian Plainview points (ca. 8200 B.C.) have been excavated at $41 \mathrm{BX} 229$ and al so recently reported from an area southwest of 41 BX 52; current1y the CAR-UTSA is attempting to redefine site locations here and assess the extent of cultural deposits.

Sites reflecting Archaic period occupations (ca. 5000 B.C.-A.D. 900) dominate the prehistoric record of northern Bexar County. Such sites as 41 BX 228, $41 \mathrm{BX} 229,41 \mathrm{BX} 300$, and $41 \mathrm{BX} 22$ represent major occupation areas with recurring activities that often span more than 4000 years of prehistory. These 1 arge Archaic campsites are often characterized by accumulations of burned rock, burned rock cluster features, and a wide variety of 1 ithic debris, projectile points, and other stone tools. Chronologically diagnostic (Archaic) projectile points commonly found in northern Bexar County are related, morphologically and in stratigraphic context, to those types common 1 y recognized for "central Texas." Early Archaic points are EarlyCorner Notched, Martindale, Gower, and Be1 1 (ca. 5000-3000 B.C.), as wel1 as 1 ater in time types, Nolan, Travis, and La Jita (ca. 3000-2000 B.C.). Middle Archaic index markers include Pedernales and Langtry (ca. 2000-650 B.C.). Monte 11. Castrovi11 e, and Marcos types (ca. 650 B.C.-A.D. 250) are associated with the Late Archaic period, followed by such types as Frio and Ensor (A.D. 250-900).

The Late Prehistoric period is represented by such chronological diagnostics as Scallorn and Edwards arrow points (ca. A.D. 900-1300) and more recent Perdiz arrow points (A.D. $1300+$ ) and undecorated Leon Plain ceramics. The remains of historic Indian sites and materials are poorly represented in the local archaeological record, although a chert gunflint was collected at site 41 BX 638 along Leon Creek, ca. $4 \mathrm{~km}$ south of Eisenhower Park, and the 1 argest collection of prehistoric (or perhaps historic Indian) ceramics was identified at $41 \mathrm{BX} 338$, ca. $8 \mathrm{~km}$ southeast of the project area.

In summary, the archaeological record of northern Bexar County is typified by 1 arge occupation sites situated along the terraces of mainstream or tributary channels of the Leon Creek or Salado Creek drainages. Large quarry workshop sites, often more than a kilometer in length, are located along the relatively flat ledge chert exposures of the Edwards formation. Small 1 ithic reduction/workshop sites characterized by evidences of temporary camping activities are commonly found in up 7 and contexts; very often these sites, because of their location on hilltops and slopes, are severely impacted by natural erosion. 


\section{SITE DESCRIPTIONS}

Six archaeological sites and one isolated find locality were assessed during current work. Two of the prehistoric site locations, 41 BX 395 and 41 BX 399, were previously recorded. A11 site assessments are based on surface examination and subsurface testing.

\section{$41 \mathrm{BX} 399$ (previously recorded)}

Iype of Site: Prehistoric 1 ithic workshop area with 1 ight (temporary) occupation activities in some scattered locales.

Dimensions: This site extends northward, beyond the survey area, into a restricted Camp Bul1is (U.S. Army) military zone. Dimensions of site within survey area are ca. $200 \times 150 \mathrm{~m}$.

Location: The site is situated along the top and upper slopes of Bush Hill, in the northwest margins of the park area.

Topographic Context: The site is located on a hilltop and upper slopes. The 1 ocale overlooks portions of the Leon Creek floodplain, ca. $0.5 \mathrm{~km}$ to the northwest, and has overviews to most of the park area.

Elevations: $1320-1340$ feet above mean sea leve1 (ms 1).

Water Source: The site is located in an upland context with no water source noted within ca. $400 \mathrm{~m}$. Evidences of a smal1 spring, now dry, are situated near the base of Bush Hil1, Ca. $400 \mathrm{~m}$ to the southeast. Gerstle, Kel1y, and Assad (1978:146), who recorded the site original1y, noted Salado Creek as a water source within one kilometer. This is somewhat of an optimistic projection, given the foreseeable difficulty in negotiating the extremely steep sloping terrain in the direction of this water source. This measurement was a 1 so based from a position on Laurin Hi11, an additional 400 m northward. Since Sal ado Creek meanders southeastward, away from the current project area, the distance from Bush $\mathrm{Hil} 1$ to Salado Creek is estimated at two or more kilometers.

Yegetation and Soils: The site and surrounding hil top areas consist of uncleared thorn brush and dense stands of juniper interspersed with sma 11 grassy areas and prickly pear. Some 1 ive oak, huisache, hackberry, and mountain 1 aurel were also noted. The soil is composed of a very shallow (often less than $12 \mathrm{~cm}$ thick) light yellowish brown calcareous stony matrix overlying 1 imestone. Numerous bedrock exposures along the steep slopes indicate the 7 ack of soil cover and extent of past erosion.

Site Condition: The site is extensively disturbed by long-term natural erosional processes. Because of the steep slopes, 1 ack of soil cover, and erosion, site integrity is considered to be nonexistent.

Site Discussion: The site was first recorded in 1978 by Gerstle, Kel1y, and Assad (1978) during survey transects when the area was still part of the Camp Bul1 is Military Reservation. The location was described as a very low 
density 1 ithic scatter, ca. $500 \mathrm{~m}^{2}$ covering both Laurin and Bush Hil $1 \mathrm{~s}$ as identified on USGS topographic maps. Three unidentified point fragments were collected from an area ca. $200 \mathrm{~m}$ north beyond the present park boundary on the eastern margins of Bush Hill.

Unidentified by Gerst1e, Kel1y, and Assad (1978:90, Fig. 20, C,g), two of these specimens, although too fragmented for a definitive assessment, do general ly follow the morphology of the Uvalde type as described by Turner and Hester (1985:155). This Early Archaic type is only broadly defined across central Texas, and its morphology varies widely. As a result of five transects over the site area an additional three retouched bifaces ("scrapers") were collected, and a light scatter of 1 ithic debris, including core fragments, decorticate and corticate chips, and flakes was noted. No features were noted, and material concentrations were estimated to be along the eastern margins of Bush $\mathrm{Hil} 1$ and toward Laurin Hill farther north (both of these areas are beyond the current project location). The site was briefly summarized as the remains of an Archaic quarry site reflecting initial as well as tertiary 1 ithic reduction activities. Intensive survey and mapping were recommended as further work.

The 1978 site assessment does not agree with the map in the Gerst7e, Ke17y, and Assad (1978:117, Fig. 34) report that projects a no chert zone across the current project area, which is north of an identified geologic fault 1 ine. Additionally, the original site description does not address the widely varying topography of the 1 ocal area. The described site area includes portions of two hilltops and their slopes-a difference in elevation of at least 80 feet.

Gerstle, Kel1y, and Assad (1978:343-344) recommended that, because 41 BX 399 was probably located at a major source of 1 arge chert nodules, intensive survey and mapping should be initiated. Site function, material distribution, and physical context were reassessed during this current work, and these evaluations (especially the 1 atter, mapping) were reconsidered. While the 1985 work considered intensive survey combined with systematic subsurface testing to be a necessity in more accurately describing the site, mapping was considered to be more difficult and less productive or useful. This reevaluation was based upon several factors: (1) most of the originally defined site area is located northward beyond the public park's boundary, and only an estimated $10 \%$ of the described site area is in current park property; (2) the dense cedar and thorn brush across this portion of the site area would have made mapping of the identified site location extremely difficult and time consuming; and (3) the steep slopes and shallow to nonexistent soils indicated that the physical context of site materials and site integrity as a whole had been severely affected by natural erosion, e.g., colluvial slope wash. The mapping of a disturbed, 1 ight scatter of 1 ithic debris formerly transported from upslope locations was not considered to be archaeologically productive. As discussed in the Field Methodology section, subsurface testing in the form of multiple $50-\mathrm{cm}^{2}$ shovel tests was utilized to determine the vertical concentration, depth of deposits, and extent of site deflation.

Site 41 BX 399 was relocated and reassessed during current studies. Only a smal 1 portion of the site, the southern half of Bush Hil1, was included in the park area. The extensive site area to the north was delineated by the 
U.S. Army fence 1 ine boundary and excluded from any investigations or reassessments.

Systematic transects at ca. 25-35 m intervals through dense juniper indicated extensive exposures of 1 imestone bedrock with shal10w (1ess than $10 \mathrm{~cm}$ in depth) to nonexistent soils along the hilltop and slopes. Pockets of soil and organic debris were identified only around stands of juniper. A 1 ight scatter of 1 ithic debris (a single artifact per 10-15 $\mathrm{m}^{2}$ ) was observed across the hilltop and upper slopes. No material concentrations or features were noted. Very 1 ittle burned or fire-reddened rock was identified. Three sma 11 dart point proximal fragments (individually described 1ater) were collected from the surface over the upper slopes of the ca. 200- $\mathrm{m}^{2}$ site area; al1 three of these were found in erosional washes or 1 ying on bedrock (see Fig. 2 ). Five $50-\mathrm{cm}^{2}$ shovel tests were excavated across the site area to identify the depth of soil deposits as well as the frequency and pattern of subsurface cultural materials. Subsurface testing consisted of a judgmental sampling methodology with units located along the east-west site axis at a consistent interval of ca. $40 \mathrm{~m}$. The results of the shovel testing, screened through 1/4-inch wire mesh, are summarized in Table 1.

\section{Artifacts Collected:}

Specimen l (Fig. 3,a): This specimen is manufactured from a medium grayish brown, fine-grained chert. The blade fragment shows evidence of a snap fracture on the distal end. Minute step fractures along the same end suggest possible reutilization in a scraperlike function. The shoulder of one blade edge has been snapped as wel1 as the basal end on this same side. The remaining morphology of the artifact indicates a basal section with we11defined blade shoulders and a bifurcated base. It is similar to the Late Archaic Montel 1 type but more 1 ikely is of the Pedernales type, dating to the Middle Archaic.

Provenience: Surface.

Measurements: Length, $3.6 \mathrm{~cm}$; width, $3.4 \mathrm{~cm}$; thickness, $0.64 \mathrm{~cm}$; weight, $8.5 \mathrm{~g}$.

Specimen 2(Fig. 3,b): This reworked basal fragment is of a medium grayish brown, fine-grained chert similar to Specimen 1. The base is strongly curved (concave), and the flared basal corners give it an almost recurved appearance. The stem length is relatively $1 \mathrm{ong}, \mathrm{ca} .1 .9 \mathrm{~cm}$, and may indicate a modification of the original blade notching point by oblique pressure flaking from the basal corners. The artifact is considered to be untyped and has broad similarities to the Early Archaic Uvalde type described by Suhm and Jelks (1962:255) and Turner and Hester (1985:155). Black and McGraw (1985:122) al so comment on the similarities and differences of the Uvalde point to other untyped points of the nearby Salado Creek drainage; unfortunately, the present specimen is too fragmented and reworked for a clearer definition. Given the general characteristics of its morphology, the specimen is estimated to be a variant of the highly variable series known as Early Corner Notched points, found in the region and dating to the Early Archaic. 
This page has been

redacted because it

contains restricted

information. 
TABLE 1. RESULTS OF SUBSURFACE TESTING, 41 BX 399

\begin{tabular}{|c|c|c|c|}
\hline $\begin{array}{l}\text { Shove 1 Test } \\
\text { Number } \\
\left(50 \mathrm{~cm}^{2}\right)\end{array}$ & $\begin{array}{l}\text { Depth of } \\
\text { Soil Deposit } \\
\text { (to bedrock) }\end{array}$ & $\begin{array}{l}\text { Excavated } \\
\text { Leve1 }\end{array}$ & Materials Recovered \\
\hline \multirow[t]{3}{*}{1} & $13 \mathrm{~cm}$ & $0-10 \mathrm{~cm}$ & 2 decorticate chips \\
\hline & & & $\begin{array}{l}1 \text { tertiary flake, single } \\
\text { faceted platform, fire- } \\
\text { reddened }\end{array}$ \\
\hline & & $10-13 \mathrm{~cm}$ & $\begin{array}{l}1 \text { corticate chip, moderately } \\
\text { patinated }\end{array}$ \\
\hline \multirow[t]{4}{*}{2} & $22 \mathrm{~cm}$ & $0-10 \mathrm{~cm}$ & I secondary flake \\
\hline & & & 3 decorticate chips \\
\hline & & & $\begin{array}{l}1 \text { tertiary flake, single } \\
\text { faceted platform }\end{array}$ \\
\hline & & $10-22 \mathrm{~cm}$ & I decorticate chip \\
\hline 3 & $17 \mathrm{~cm}$ & & sterile \\
\hline \multirow[t]{5}{*}{4} & $26 \mathrm{~cm}$ & $0-10 \mathrm{~cm}$ & 1 decorticate chip \\
\hline & & & 1 corticate chip \\
\hline & & $10-20 \mathrm{~cm}$ & $\begin{array}{l}\text { I small burned limestone } \\
\text { fragment }\end{array}$ \\
\hline & & & $\begin{array}{l}1 \text { tertiary flake, multi- } \\
\text { faceted platform }\end{array}$ \\
\hline & & $20-26 \mathrm{~cm}$ & sterile \\
\hline \multirow[t]{2}{*}{5} & $14 \mathrm{~cm}$ & $0-10 \mathrm{~cm}$ & 1 decorticate chip \\
\hline & & $10-14 \mathrm{~cm}$ & 1 decorticate chip \\
\hline
\end{tabular}




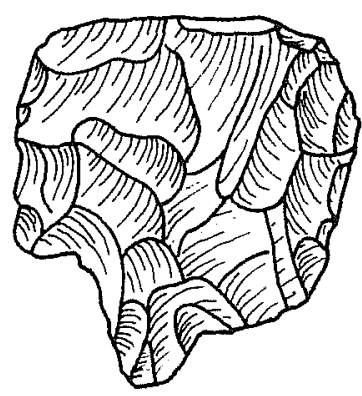

a

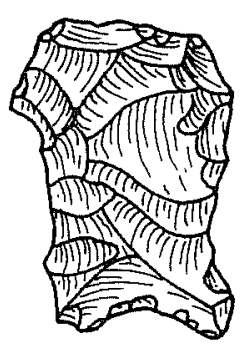

b

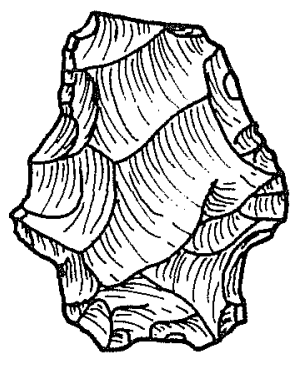

c

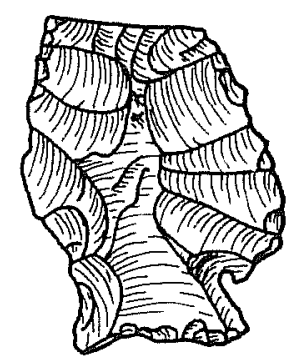

d

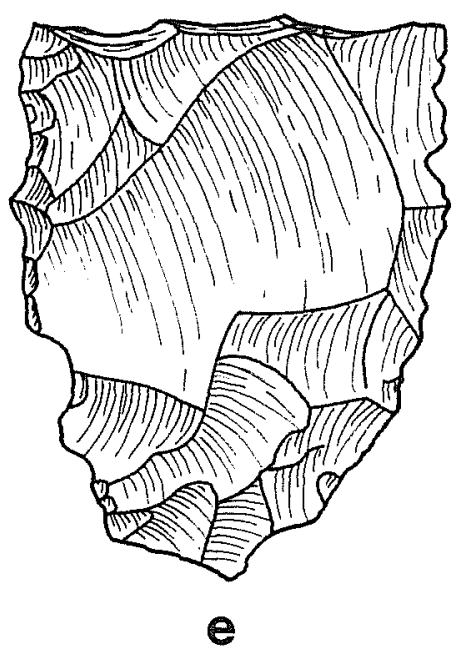

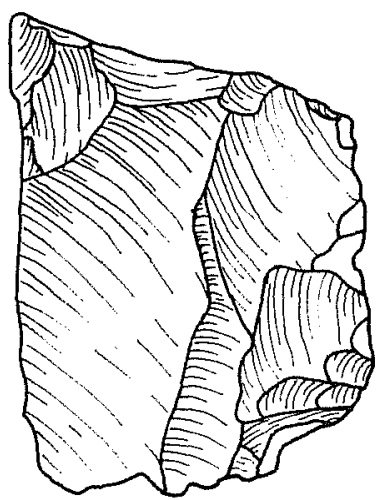

f

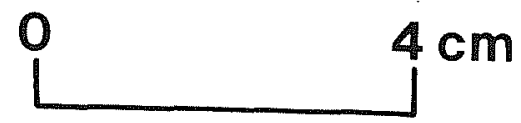

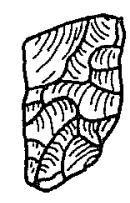

h

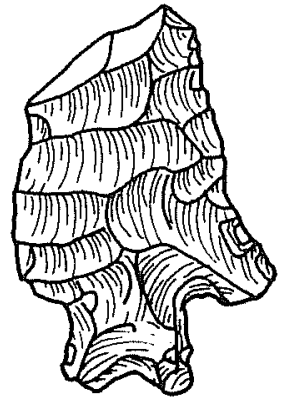

i

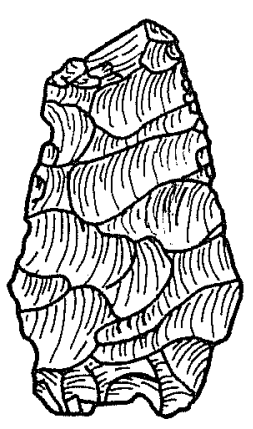

j

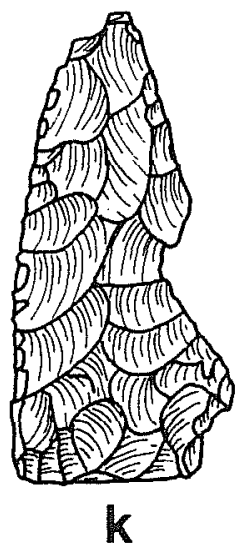

Figure 3. Col1ected Artifacts. a, Specimen 1, 41 BX 399; b, Specimen 2, 41 BX 399; c, Specimen 3, 41 BX 399; d, Specimen 1, 41 BX 395; e, Specimen 1. 41 BX 701; f, Specimen 2, 41 BX 701; g. Specimen 3, 41 BX 701; h, Specimen 4, 41 BX 70I; $i$, Specimen 1, 41 BX 702; $j$, Specimen 2, 41 BX 702; k, Isolated Find. 
Provenience: Surface.

Measurements: Length, $3.0 \mathrm{~cm}$; weight, $2.4 \mathrm{~cm}$; thickness, $1.6 \mathrm{~cm}$; weight, $5.0 \mathrm{~g}$.

Specimen 3 (Fig. 3,C): Extensively patinated on both faces, this projectile point fragment has been reworked. Soft-hammer or pressure flaking resulting in oblique $f l a k e$ scars across the blade (done during reworking?) are reminiscent of the flaking pattern on Specimen 2. Fragmentation of the original artifact precludes type identification: given the degree of patination, flaking pattern, and conjectural original shape, it is estimated the specimen is the remains of a projectile point of Early Archaic age.

Provenience: Surface.

Measurements: Length, $3.3 \mathrm{~cm}$; width, $3.1 \mathrm{~cm}$; thickness, $0.8 \mathrm{~cm}$; weight, $7.5 \mathrm{~g}$.

Site Assessment: The portion of 41 BX 399 that is located within the Eisenhower Park property is characterized by a 1 ight, deflated scatter of 7 ithic debris across the upper slopes and crest of Bush Hill. Little evidence of fire-burned rock and no features were observed across the site area, ca. $150 \times 200-250 \mathrm{~m}$.

Although Gerstle, Kelly, and Assad (1978:344) suggested this area was a large quarry site, this was not noted in the portion of 41 BX 399 investigated at Eisenhower Park. The 1 ithic scatter observed in this area is thought to represent not a quarry site but a 1 ithic workshop location, primarily reflecting secondary and tertiary 1 ithic reduction processes.

The results of current field work indicate the site area in the vicinity of Bush $\mathrm{Hill}$ is completely deflated, and no features or concentrations of materials were noted. The collected projectile point fragments and those recovered by Gerstle, Kelly, and Assad (1978:90, Fig. 20,c,g) suggest the area was exploited during the Early Archaic period. The location of Bush $\mathrm{Hil} 1$ as a high overlook above the Leon Creek drainage to the west and portions of the Salado Creek drainage to the east may account for much of the former functions of this prehistoric site.

Recommendations: Because of extensive and severe site damage by natura 1 erosion and a 1 ack of subsurface soil and cultural deposits, the portion of 41 BX 399 within the boundaries of Eisenhower Park is not considered to be eligible for National Register nomination, nor can it be designated as a State Archeological Landmark. No further work is recommended. It is recommended that the site area be identified on construction plans, so that any further damage may be avoided by future construction activities. It is al so recommended the site area be identified to personnel, such as park rangers, who would monitor this location to avoid possible site damage by relic collectors. 
$41 \mathrm{BX} 395$ (previously recorded)

Iype of site: A 1 ight scatter of prehistoric 1 ithic debris.

Dimensions: ca. $250 \times 200 \mathrm{~m}$.

Location: First described by Gerstle, Kel1y, and Assad (1978:144) as adjacent to an intermittent drainage and having a site area of $20 \times 40 \mathrm{~m}$, current work has substantially increased the site's dimensions. The locale is situated on the slopes of an ephemeral drainage in the south-central margins of the park.

Iopographic Context: Upland margins and slopes along an intermittent stream that drains Bush $\mathrm{Hi} 1$, ca. $700 \mathrm{~m}$ northwest.

Elevation: ca. 1065-1090 feet above ms 1 .

Water Source: The closest water source seems to be intermittent run-off from slopes that accumulates in a nearby drainage, ca. $25 \mathrm{~m}$ distant. A sma 11 (now dry) spring was also identified ca. $400 \mathrm{~m}$ northward along the drainage at the foot of Bush Hi11. Gerst1e, Kel1y, and Assad (1978:144) al so mention that Salado Creek is within one kilometer. In actuality, the distance is closer to two kilometers.

Vegetation and Soils: $C 1$ imax vegetation is dominated by a dense growth of juniper throughout the area. Short to medium grasses cover the ground, interspersed with occasional stands of prickly pear cactus. A very thin 1 ayer of 1 ight brown calcareous soil covers the area, and exposures of 1 imestone bedrock occur frequent]y.

Site condition: The site is extensively disturbed by 1ong-term erosion. The original integrity of cultural deposits is severely affected by soil depletion, and the entire site area is considered deflated.

Site Discussion: The site was first identified in 1978 by Gerstle, Kel1y, and Assad, who described it as an upland margins site with dimensions of ca. $20 \times 40 \mathrm{~m}$. The original surveyors noted the site contained a scatter of core fragments as wel1 as other corticate and decorticate 1 ithic debitage. Recovered from a $2-\mathrm{m}^{2}$ surface collection unit were four fragments of debris. Site 41 BX 395 was identified as an initial reduction/chert quality testing site. Gerstle, Kelly, and Assad (1978) recommended a possible controlled surface collection and mapping. It should be noted that, because of the field methodology employed in 1978, representative transect sampling, the full surface extent of the 1 ithic scatter was not realized until intensive survey in 1985.

In the process of relocating 41 BX 395 during current work, it was found that the original site area is the northern 1 imit of a very 1 ight scatter of 1 ithic debris that extends southward to the southeastern park boundary for a distance of ca. $250 \mathrm{~m}$. Lithic debris density on the surface of this area was observed to be minimal and, except for the originally defined location, never exceeded one fragment per $20 \mathrm{~m}^{2}$. Five $50-\mathrm{cm}^{2}$ shovel tests, spaced at ca. 50-m intervals, were excavated along the long axis of this location (site 
TABLE 2. RESULTS OF SUBSURFACE TESTING, 41 BX 395

\begin{tabular}{|c|c|c|c|}
\hline $\begin{array}{l}\text { Shovel Test } \\
\text { Number } \\
\left(50 \mathrm{~cm}^{2}\right)\end{array}$ & $\begin{array}{l}\text { Depth of Soil Deposit } \\
\text { (to bedrock) }\end{array}$ & $\begin{array}{c}\text { Excavated } \\
\text { Leve1 }\end{array}$ & $\begin{array}{l}\text { Materials } \\
\text { Recovered }\end{array}$ \\
\hline 1 & $18 \mathrm{~cm}$ & $\begin{array}{r}0-10 \mathrm{~cm} \\
10-18 \mathrm{~cm}\end{array}$ & $\begin{array}{l}\text { sterile } \\
\text { sterile }\end{array}$ \\
\hline 2 & $13 \mathrm{~cm}$ & $\begin{array}{l}0-10 \mathrm{~cm} \\
10-13 \mathrm{~cm}\end{array}$ & $\begin{array}{l}1 \text { decorticate } \\
\text { chip } \\
\text { sterile }\end{array}$ \\
\hline 3 & $9 \mathrm{~cm}$ & & sterile \\
\hline 4 & $21 \mathrm{~cm}$ & $\begin{array}{l}0-10 \mathrm{~cm} \\
10-21 \mathrm{~cm}\end{array}$ & $\begin{array}{l}1 \text { tertiary } \\
\text { flake } \\
1 \text { decorticate } \\
\text { chip } \\
\text { sterile }\end{array}$ \\
\hline 5 & $9 \mathrm{~cm}$ & $0-9 \mathrm{~cm}$ & $\begin{array}{l}2 \text { corticate } \\
\text { chips }\end{array}$ \\
\hline
\end{tabular}

width varied from ca. $200 \mathrm{~m}$ in the southern portion to ca. $75 \mathrm{~m}$ in the northern section). The results of these shovel tests are presented in Table 2.

During the course of intensive survey, which located surface materials concentrated in the northern portion of the site (in the vicinity of the originally defined site area), the proximal portion of a small dart point was found ca. $20 \mathrm{~m}$ north of the park fence 1 ine in the southern half of the site.

After a consideration of the paucity of both surface and subsurface material as wel1 as the observed site deflation, it was thought that site mapping would accomplish 1 ittle toward a clearer understanding of site function or significance of material distributions. Efforts were then, through intensive survey, toward the identification of a concentration of surface material, with the intention of establishing a controlled surface collection in this area.

Fol lowing the identification of a surface material concentration, a $10-\mathrm{m}^{2}$ unit was established in this area for a controlled surface collection. Eight 
fragments of 1 ithic debris were collected: five corticate chips, one singlefaceted tertiary $f 1$ ake, and two decorticate chips. No other materials, features, or burned rock were noted or collected.

\section{Artifacts Collected:}

Smal1 Dart Point (Fig. 3,d): The projectile point fragment is characterized by a corner notched, expanding stem and a slightly concave basal end. Blade edges have been extensively reworked, and both barbs are missing. The point is similar in morphology to an unnamed form (D4:2) identified by B 1 ack and McGraw (1985:122) as a variety of the Early Corner Notched series, dating to the Early Archaic Period.

Measurements: Length, $3.2 \mathrm{~cm}$; width, $2.6 \mathrm{~cm}$; thickness, $0.45 \mathrm{~cm}$; weight, $4.5 \mathrm{~g}$.

Site Assessment: Based on intensive survey, 1 imited testing, and controlled surface collection, 41 BX 395 is identified as a 1 ithic workshop site characterized by a light scatter of debitage along the upland margins of an intermittent stream channe1. Site dimensions, based on the distribution of a very low surface artifact density, are estimated at $250 \times 200 \mathrm{~m}$ in the southern portion of the site and narrowing to a width of ca. $75 \mathrm{~m}$ in the northern 1 imits. The long axis of the site follows the intermittent drainage channel northward and may indicate a former proximity to a small water source.

Recommendations: Because of the lack of significant cultural materials from the 1 imited testing and controlled surface collection and the overall observed site deflation, site 41 BX 395 is not considered eligible to be nominated to the National Register of Historic Places or designated as a State Archeological Landmark. No further work is recommended at this location.

\section{BX 700 (newly identified)}

Iype of Site: Prehistoric 1 ithic workshop and possibly temporary occupation.

Dimensions: ca. $25 \mathrm{~m}$ in diameter.

Lecation: Approximately $300 \mathrm{~m}$ south of Bush Hill and $0.7 \mathrm{~km}$ north of the southern fence line of the park.

Tepographic Context: Adjacent to the upper slopes (upland margin) of a smal1, intermittent drainage that received run-off from Bush Hill.

Elevation: 1140 feet above msl.

Water Source: The site is currently situated near a dry tributary channel. A smal1 spring (now dry) ca. 300-400 m upstream may have also once furnished a smal1 amount of water in this channel. 
Vegetation and Soils: The site and surrounding area are covered by short to medium grasses. Dense stands of juniper occur along the upland margins with sotol and prickly pear cactus. Some oak and other deciduous trees 1 ine the lower slopes of the drainage. The 1 ight brown soil is eroded, shallow, and calcareous.

Site condition: The site is somewhat deflated by natural erosion. No modern adverse impacts were noted.

Site Discussion: Collected from the surface of this site location were five fragments of 1 ithic debris: two smal1 core fragments, one corticate chip, and two small primary flakes. Al1 debris is made of a 1 ight tan chert. No burned rock fragments or features were noted in this 1 ocation. Two $50-\mathrm{cm}^{2}$ shove 1 tests were excavated at this location to a maximum depth of $19 \mathrm{~cm}$ (to bedrock). Shovel test 1 recovered one decorticate and two decorticate chips at $7 \mathrm{~cm}$; shove 1 test 2, ca. $15 \mathrm{~m}$ distant, was sterile. No other features or materials were noted or observed.

Artifacts collected: Only 1 ithic debris as previously discussed were recovered.

Site Assessment: Site $41 \mathrm{BX} 700$ is bel ieved to be the remains of a sma 11 , temporary 1 ithic workshop station, perhaps consisting of a single episode of activity revolving around initial 1 ithic reduction. While such a smal1, discrete area may shed insights into individual 1 ithic reduction techniques, the extreme paucity of materials and 1 ack of soil depth related to long-term erosion negate the potential research value.

Recommendations: The site does not meet the eligibility criteria for nomination to the National Register or to be designated as a State Archeological Landmark. No further work is recommended in this area.

\section{$41 \mathrm{BX} 701$ (newly identified)}

Iype of Site: Prehistoric scatter of 1 ithic debris. Several scattered fragments of burned and fire-fractured 1 imestone rock indicate that temporary camping activities may have occurred at this location.

Dimensions: ca. $50 \times 70 \mathrm{~m}$.

Lecation: At the southern base of Bush Hill and near the head of a sma 11 , intermittent run-off channel that meanders southward from this point.

Iopographic Context: The 1ocale forms the beginning of a small drainage at the base of Bush Hil1. The remains of a smal1, natural seep spring is located at this point.

Elevation: 1165 feet above ms1.

Water source: In present times, the intermittent drainage is dry. A source of water may have once been found at the small spring (see above). 
Vegetation and Soils: Numerous exposures of 1 imestone bedrock outcrop in this vicinity. A medium brown, calcareous soil 7 ayer thinly overlies this 1 imestone. Soil depth varies from 1 ess than $10 \mathrm{~cm}$ to pockets of almost $50 \mathrm{~cm}$ (where humus has formed around groups of oak and juniper). Vegetation consists of short grasses and occasionally prickly pear cactus; oak and juniper dominate the climax flora.

Site Condition: Surface and subsurface examinations show 1 ittle depth of cultural materials, and the site appears deflated.

Site Discussion: This small area of prehistoric activity is characterized by a light scatter of 1 ithic debris composed of corticate and decorticate chips and primary, secondary, and tertiary $\mathrm{f} 7$ akes. Temporary camping activities may be indicated by several small burned rock fragments scattered throughout the site area.

Two thick (more than one centimeter) proximal biface fragments, one medial projectile point fragment, and the barb from a projectile point blade were collected from the surface. A more complete description of this material follows.

Two $50-\mathrm{cm}^{2}$ shovel tests were excavated to determine depth and intensity of possible subsurface materials. Shovel test 1 , it should be noted, was excavated along a terrace slope in a small pocket of soil ca. $10 \mathrm{~m}^{2}$ beneath a group of juniper. It is possible that this material actually represents a disturbed, transported collection from farther upslope. A 1 ist of the materials collected from the two shovel tests is presented in Table 3.

TABLE 3. RESULTS OF SUBSURFACE TESTING, 41 BX 701

\begin{tabular}{|c|c|c|c|}
\hline $\begin{array}{l}\text { Shovel } \\
\text { Test No. }\end{array}$ & $\begin{array}{c}\text { Depth of Soil } \\
\text { Deposit }\end{array}$ & $\begin{array}{c}\text { Excavated } \\
\text { Level }\end{array}$ & $\begin{array}{l}\text { Materials } \\
\text { Recovered }\end{array}$ \\
\hline \multirow[t]{3}{*}{1} & $32 \mathrm{~cm}$ & $0-10 \mathrm{~cm}$ & $\begin{array}{l}1 \text { secondary flake } \\
4 \text { decorticate chips } \\
4 \text { corticate chips }\end{array}$ \\
\hline & & $10-20 \mathrm{~cm}$ & $\begin{array}{l}1 \text { tertiary flake } \\
1 \text { decorticate chip } \\
1 \text { core fragment }\end{array}$ \\
\hline & & $20-32 \mathrm{~cm}$ & sterile \\
\hline 2 & $14 \mathrm{~cm}$ & $0-10 \mathrm{~cm}$ & $\begin{array}{l}3 \text { corticate chips } \\
2 \text { decorticate chips } \\
1 \text { tertiary flake }\end{array}$ \\
\hline
\end{tabular}


The results of subsurface testing as well as intensive survey of this sma 11 lithic scatter indicate that a light scatter of 1 ithic debris exists on the surface and just below the surface at this site location. No features or otherwise significant materials were noted or collected.

\section{Artifacts Collected:}

Specimen I (Fig. 3,e): This specimen consists of a completely patinated triangular biface fragment fractured along the short central axis. Primarily billet flaked, portions of the biface edge are pressure flaked, suggesting edge rejuvenation or perhaps later reutilization.

Provenience: Surface.

Measurements: Length, $5.5 \mathrm{~cm}$; width, $5.14 \mathrm{~cm}$; thickness, $1.25 \mathrm{~cm}$; weight, $33 \mathrm{~g}$.

Specimen 2 (Fig. 3,f): This we11-patinated artifact is the proximal fragment of a thick biface. The ventral edge is characterized by marginal edge retouch in the form of pressure $f 1$ aking; $a 11$ other $f 1$ ake scars across ventral and dorsal faces appear to be soft hammer percussion flaked.

Provenience: Surface.

Measurements: Length, $3.35 \mathrm{~cm}$; width, $4.45 \mathrm{~cm}$; thickness, $1.14 \mathrm{~cm}$; weight, $24.5 \mathrm{~g}$.

Specimen 3 (Fig. 3,g): This specimen is the medial fragment of a small, thin biface thought to have probably functioned as a projectile point. Knapped from a coarse-grained tan chert, the artifact is extensively patinated.

Provenience: Surface.

Measurements: Length, $2.30 \mathrm{~cm}$; width, $2.26 \mathrm{~cm}$; thickness, $0.70 \mathrm{~cm}$; weight, $5.0 \mathrm{~g}$.

Specimen 4 (Fig. 3,h): This small, finely worked projectile point barb is completely patinated. While it is not possible to identify the diagnostic context of the original artifact, it is suggested the morphology of this fragment is similar to other Early Archaic projectile points known as Bell (cf. Turner and Hester 1985:72).

Provenience: Surface.

Measurements: Length, $1.60 \mathrm{~cm}$; width, $0.94 \mathrm{~cm}$; thickness, $0.33 \mathrm{~cm}$; weight, $0.5 \mathrm{~g}$.

Site Assessment: Artifact recovery frequency was minimal from both intensive survey and subsurface testing. The presence of a fragmentary barb from a dart point (Early Archaic?) suggests at least some activities from this small 1 ithic workshop site may be related to the Early Archaic. 
Recommendations: The site does not meet the el igibility requirements for nomination to the National Register of Historic Places or to be designated as a State Archeological Landmark. No further work is recommended at this location.

\section{$41 \mathrm{BX} 702$}

Iype of Site: Prehistoric 1ithic scatter.

Dimensions: ca. $120 \times 75 \mathrm{~m}$.

Location: Approximate 1 y $0.85 \mathrm{~km}$ east of the western park fence 1 ine and $0.75 \mathrm{~km}$ south of Bush Hil1.

Topographic Context: Along an upland ridge.

Elevation: 1125 feet above ms 1.

Water Source: None within $400 \mathrm{~m}$; an intermittent drainage 7 ies ca. $400 \mathrm{~m}$ to the east.

Vegetation and Soils: Short grasses and juniper cover the site area. The soil in the area is thin (less than $12 \mathrm{~cm}$ ), tan-colored, and calcareous with numerous 1 imestone bedrock exposures.

Site Condition: The site is extensively eroded and deflated.

Site Discussion: A light scatter of lithic debris, with a density of less than two artifacts per $25 \mathrm{~m}^{2}$, characterizes the surface of this site. Corticate and decorticate chips dominated the surface materials observed. Two smal1 proximal projectile point fragments (described in more detail following) were surface collected from the site.

In addition to intensive survey, two $50-\mathrm{cm}^{2}$ shovel tests were excavated to depths of $35 \mathrm{~cm}$ across the site area. Both test units were sterile, and no features or other significant materials were noted in surface or subsurface contexts.

\section{Artifacts Collected:}

Specimen I (Fig. 3,i): This extensively patinated specimen is characterized by broad corner notching and a slightly expanding stem with a small concave basal end. Blade edges are recurved, suggesting previous blade edge modification or resharpening. The unidentified point fragment is generaliy similar to Group 4, Form 1, unnamed Early Expanding Stem varieties from 41 BX 228 (B 1 ack and McGraw 1985:121-123).

Provenience: Surface.

Measurements: Length, $3.74 \mathrm{~cm}$; width, $2.68 \mathrm{~cm}$; thickness, $6.8 \mathrm{~cm}$; weight, $6.1 \mathrm{~g}$. 
Specimen 2 (Fig. 3,j): This artifact, untyped, is distinguished by its extensively reworked blade and shoulders. Reworking of the blade has altered the shape to where its original morphology can no longer be easily identified. The 1 ack of patination suggests a relatively younger age than Specimen 1.

Provenience: Surface.

Measurements: Length, $3.94 \mathrm{~cm}$; width, $2.28 \mathrm{~cm}$; thickness, $0.57 \mathrm{~cm}$; weight, $5.5 \mathrm{~g}$.

Site Assessment: Site 41 BX 702 is identified as a 1 ight scatter of 1 ithic debitage in an up 1 and context. It is thought to represent the remains of a temporary workshop station that has been extensively affected and deflated by natural erosional processes. The presence of two broken projectile points suggests at least some (Early Archaic?) upland activity in this area, and the relative 1 ack of patination on Specimen 2 may indicate 1 ater, sporadic, and temporary interest.

Recommendations: Because of the infrequency of materia1s, 1 ack of subsurface materials, and eroded and damaged site condition, no further work is recommended in this area. The site does not meet the eligibility requirements to be nominated to the National Register or to be designated as a State Archeological Landmark.

\section{$41 \mathrm{BX} 703$}

Iype of Site: A light scatter of prehistoric lithic debris.

Dimensions: ca. $75 \times 50 \mathrm{~m}$.

Lecation: Along the upper slopes of an extensive ridge complex near the south-central margins of the park area.

Topegraphic Context: The site is situated on the southeastern slopes of an extensive upland hill/ridge complex. The overview, to the southeast, is quite extensive, and is in the general direction of the Salado Creek drainage, ca. $1.7 \mathrm{~km}$ away.

Elevation: 1160 feet above msl.

Water Source: None noted. The site is within a distinctly upland context. A smal1, intermittent drainage in the vicinity of 41 BX 395 is located ca. $350 \mathrm{~m}$ to the east.

Vegetation and Soils: Short grasses and scattered stands of juniper cover the site area. Extensive exposures of bedrock indicate a shallow to nonexistent thin, calcareous soil zone.

Site Condition: Severely deflated by natural erosional processes. 
Site Discussion: Over the site area is a light to very light scatter of decorticate and corticate chips and an occasional flake. Several fragments of this debitage were observed to be 1 aying on exposed bedrock along the slope. A single $50-\mathrm{cm}^{2}$ shovel test was excavated in a shallow soil deposit near the upper site margins. Although the test unit was excavated to bedrock, ca. $15 \mathrm{~cm}$, no cultural materials were uncovered. No chronologically diagnostic or otherwise significant features were recovered or observed in the site area.

Site Assessment: Site 41 BX 703 is similar to the other 7 ight scatters of lithic debris identified and assessed in the study area. It is characterized by a paucity of cultural remains in a severely disturbed context. No features or significant materials were noted.

Recommendations: No further work is recommended at this site. The site does not meet eligibility requirements to be nominated to the National Register of Historic Places or to be designated as a State Archeological Landmark.

\section{ISOLATED FIND LOCALITY}

A single small projectile point fragment was recovered during survey transects in the south-central portion of the study area, ca. $200 \mathrm{~m}$ north of $41 \mathrm{BX} 703$ and $400 \mathrm{~m}$ west of $41 \mathrm{BX} 702$ (Fig. 2). This artifact (Fig. 3,k) consists of the lateral blade edge of a smal1, thin biface. Extensive fracturing along the end and side of the blade precludes identification of proximal and distal ends. The intact blade edge reflects distinctive, steep edge beveling. The specimen is moderately patinated and may be the remains of an extensively reworked 1 anceolate biface.

Measurements: Length, $6.68 \mathrm{~cm}$; width, $2.25 \mathrm{~cm}$; thickness, $6.7 \mathrm{~cm}$; weight, $9.0 \mathrm{~g}$.

\section{SUMMARY}

A detailed examination of the two previously recorded archaeological sites as we 11 as four new $1 y$ identified locations indicates the study area has been severely affected by a long history of natural erosional processes. This has led to the deflation of cultural materials which were once deposited on shallow soils in sloping, up 1 and contexts. This interpretation of the physical contexts of these aboriginal sites in this area has led to some changes in the investigative strategy and field methodology for this current work in contrast to previous, preliminary recommendations (Gerstle, Kelly, and Assad 1978). It is felt that the current approach of intensive survey, selective subsurface testing, and appropriately control led surface collection more effectively and accurately assess the integrity and significance of the sites in this area.

The aboriginal sites of the project area reflect a long history of sporadic, temporary activities across the up 1 and 1 andscape between the Leon Creek and Salado Creek watersheds. The value of these deflated sites in eroded, upland contexts does not 1 ie in the significance of the (disturbed) material 
evidence but in the identification of such sites in their physiographic and chronological contexts. Such data should offer broader insights of prehistoric patterns of exploitation, especially in Early Archaic times, to future researchers of the archaeological record of Bexar County.

Although the cultural resources identified in the Eisenhower Park study area require no further work, do not meet the eligibility requirements for nomination to the National Register of Historic Places, and cannot be designated as a State Archeological Landmark, it is necessary to address the preservation of these cultural remains. Most importantly, as the park becomes developed, there is a real danger of accelerated sites destruction by random or, as in other areas of the Salado Creek drainage, systematic illegal relic collecting. Such effects can in a large part be mitigated by the awareness of park personnel and the formal and informal continued monitoring of these site 1 ocations. The value of these cultural resources and the legacy of their material remains are a significant aspect of this modern wilderness park. The public's awareness and enjoyment of the natural resources of Eisenhower Park today is another aspect of the continued exploitation of this same natural setting as in past times.

\section{REFERENCES CITED}

BTack, S. L. and A. J. McGraw

1985 The Panther Springs Creek Site: Cultural Change and Continuity in the Upper Sal ado Creek Watershed, South-Central Texas. Center for Archaeological Research. The University of Texas at San Antonio, Archaeological Survey Report 100.

Blair. W. F.

1950 The Biotic Provinces of Texas. The Texas Journal of Science 2(1) : 93-113.

Carr, J. T., Jr.

1967 The C1 imate and Physiography of Texas. Texas Water Development Board, Report 53. Austin.

Dibble, D.

1979 Archeological Reconnaissance in the Salado Creek Watershed, Bexar County, Texas. Texas Archeological Salvage Project. The University of Texas at Austin. Survey Report 9.

Fawcett, W. B., Jr.

1972 The Prehistory of Bexar County: A Study of Previous Work in South. Central Texas. Bulletin of the Lower Plains Archeological Society 2:23-43. 
Fox, D.

n.d. Manuscript on file, Center for Archaeological Research. The University of Texas at San Antonio.

Freese and Nichols, Inc.

1977 Environmental Statement, Overall Mission, Fort Sam Houstons Texas. Department of the Army Headquarters, Forces Command.

Gerst7e, A., T. C. Kel1y, and C. Assad

1978 The Fort Sam Houston Project: An Archaeological and Historical Assessment. Center for Archaeological Research. The University of Texas at San Antonio, Archaeological Survey Report 40.

McGraw, A. J. and V. K. Hindes

n.d. El Rio Medina: La Historia de los Indios Prehistoricas y los Primeros Pobladores: A Phase II Cultural Resources Assessment of the Proposed Applewhite Reservoir. Center for Archaeo1 ogical Research. The University of Texas at San Antonio, Archaeological Survey Report 163. In draft.

McGraw, A. J. and F. Valdez, Jr.

1978a Investigations of Prehistoric Rockshelter and Terrace Sites Along Portions of the Sa 1 ado Creek Drainage, Northern Bexar County. Center for Archaeological Research. The University of Texas at San Antonio, Archaeological Survey Report 55.

1978b 4l BX 68: A Prehistoric Quarry Workshop in Northern Bexar County, Texas. Center for Archaeological Research, The University of Texas at San Antonio, Archaeological Survey Report 56.

McGraw, A. J., F. Valdez, Jr., and I. W. Cox

1977 Archaeological Survey of Areas Proposed for Modification in the Encino Park Development, Northern Bexar County, Texas. Center for Archaeological Research. The University of Texas at San Antonio, Archaeological Survey Report 39.

Schuetz, M. K.

1966 The Granberg Site: An Archajc Habitation in Bexar County, Texas. Witte Memorial Museum, Studies 1. San Antonio. 
24

Sum, D. A. and E. B. Jerks

1962 Handbook of Texas Archeology: Type Descriptions. Texas Archeological Society, Special Publication 1 and Texas Memorial Museum Bulletin 4, Austin.

Taylor, F. B., R. B. Haley, and D. L. Richmond

1966

Soil Survey of Bexar County, Texas. U.S. Department of Agriculture, Soil Conservation Service, in cooperation with the Texas Agricultural Experiment Station, Series 1962(12).

Turner, E. S. and T. R. Hester

1985

A Field Guide to Stone Artifacts of Texas Indians. Texas Month 1 y Press, Austin. 

